\title{
FINE-SCALE GENETIC STRUCTURE IN FEMALE MULE DEER (ODOCOILEUS HEMIONUS)
}

\author{
Cortney W. Noble ${ }^{1,2}$, Jeremy M. Bono ${ }^{1}$, Helen K. Pigage ${ }^{1}$, David W. Hale ${ }^{3}$, and Jon C. Pigage ${ }^{1,4}$
}

\begin{abstract}
AвSTRACT.-Fine-scale genetic structure in animal populations can have important consequences for evolutionary processes and can influence conservation and management decisions. Cervids often live in matrilineal social groups, and this spatial grouping can create fine-scale genetic structure among females. We used DNA and radio-location data at Fort Carson Military Reservation in south central Colorado, USA, to determine whether female mule deer (Odocoileus hemionus) living in close proximity were more likely to be related. Spatial data were obtained over an 18-month period using data transmitted from GPS collars. Average positions for each animal were correlated with relatedness estimates calculated using 7 microsatellite loci. We found significant spatial autocorrelation for females at distances $\leq 1000 \mathrm{~m}$, which suggests that females were frequently philopatric. In addition, females appeared to occasionally disperse over relatively longer distances, as we found evidence of related females separated by distances up to $28,000 \mathrm{~m}$. Fine-scale genetic structure may have important implications for managing chronic wasting disease, which is relatively common at this site.
\end{abstract}

RESUMEN.-La estructura genética a escala fina en poblaciones animales puede tener importantes consecuencias en los procesos evolutivos, ya que puede influir en las decisiones de conservación y gestión. A menudo, los cérvidos viven en grupos sociales matrilineales que pueden provocar una estructura genética a escala fina entre las hembras. Utilizamos datos de ADN y de radiolocalización en la Reserva Militar Fort Carson, en el centro-sur de Colorado, Estados Unidos de América, para determinar si las hembras de venado bura (Odocoileus hemionus) que viven cerca están más relacionadas entre ellas. Obtuvimos datos espaciales durante un período de 18 meses, a partir de transmisores de collares con sistemas de posicionamiento global. Las ubicaciones promedio de cada animal se combinaron con estimaciones de parentesco calculadas a partir de siete loci-microsatélites. Encontramos una autocorrelación espacial significativa entre hembras en distancias $\leq 1000 \mathrm{~m}$, lo que sugiere que las hembras son filopátricas frecuentemente. Además, las hembras parecían ocasionalmente dispersarse en distancias relativamente largas, ya que encontramos evidencia de hembras emparentadas separadas por distancias de hasta 28,000 metros. La estructura genética a una escala fina puede tener importantes implicaciones en el manejo de la caquexia crónica, que es relativamente común en esta zona.

Fine-scale genetic structure within populations is a consequence of the nonrandom spatial distribution of related individuals that results from stable social organization, limited dispersal, skewed mating success, or a combination of these factors (Storz 1999). The presence of fine-scale spatial genetic structure has important consequences for evolutionary processes and practical implications for conservation and management. For example, fine-scale genetic structure creates opportunities for kin selection (e.g., Hïglund et al. 1999, Russell and Hatchwell 2001, Cutrera et al. 2005), influences the probability of inbreeding versus outbreeding (Chesser 1991a, 1991b, Sugg et al. 1996), shapes the pattern and tempo of disease transmission (Grear et al. 2010, Cullingham et al. 2011a, 2011b), and affects the rate at which genetic diversity is lost from populations (Sugg et al. 1996).

Spatial genetic structure in mammal populations is relatively common, but the scale and degree of structuring depends on patterns of dispersal and nonrandom mating. Females of most mammal species are philopatric, commonly forming matrilineal social groups, whereas males disperse prior to breeding (Greenwood 1980). As expected, this dispersal pattern often creates fine-scale genetic structure in females, but not males, particularly when males are highly polygynous and associate permanently or semipermanently with female social groups (Storz 1999). Exceptions to this general pattern are seen in species in which dispersal is not sex-biased, and, consequently, spatial structure does not differ markedly

\footnotetext{
${ }^{1}$ Department of Biology, University of Colorado, 1420 Austin Bluffs Parkway, Colorado Springs, CO 80918-3733. 2Present address: Colorado Parks and Wildlife, 4255 Sinton Road, Colorado Springs, CO 80907.

${ }^{3}$ Department of Biology, HQ USAFA/DFB, 2355 Faculty Drive, Suite 2P389, United States Air Force Academy, CO 80840-6226.

${ }^{4}$ Corresponding author. E-mail: jpigage@uccs.edu
} 
between the sexes (e.g. Busch et al. 2009, Bonnot et al. 2010).

Cervids are social animals, but tend to have less rigid social structure than many other mammals and only a moderate degree of polygyny (Bubenik 1985). Studies of fine-scale genetic structure in cervids have revealed considerable variability in the relative degree of spatial structuring between different species, and even between populations of a single species. For example, though most cervids follow the typical mammalian pattern of finescale genetic structure among females, but not males (Comer et al. 2005, Nussey et al. 2005, Grear et al. 2010, Miller et al. 2010, Cullingham et al. 2011a, Colson et al. 2013), species such as the roe deer (Capreolus capreolus) do not exhibit differences in the pattern of spatial genetic structure between the sexes due to lack of sex-biased dispersal and weak polygyny (Bonnot et al. 2010). Moreover, variation in the extent of spatial genetic structuring in different populations of the same species, and even changes over time within a single population, suggest that fine-scale genetic structure in cervids is dynamic, being influenced by migratory behavior, population density, sex ratio, and the age structure of the population (Mathews and Porter 1993, Comer et al. 2005, Nussey et al. 2005, Grear et al. 2010, Miller et al. 2010, Cullingham et al. 2011a, 2011b, Colson et al. 2013).

Here we examine fine-scale genetic structure in a nonmigratory Colorado [USA] population of mule deer (Odocoileus hemionus) in the southern Rocky Mountain region. Mule deer are social animals and are usually found in groups (Cowan 1956). The primary social unit is centered on a reproductive female and her offspring (Mierau and Schmidt 1981, Pac et al. 1991). Even though this female/offspring group is the most stable social unit exhibited by mule deer, groups can vary seasonally and may even disband completely. Mule deer offspring show gender-related differences in the amount of time that they stay with their dams and in the distance they disperse when independent. Although both sexes may disperse, males do so more frequently and typically travel longer distances than females (Gruell and Papez 1963, Mierau and Schmidt 1981, Harestad and Bunnell 1983, Eberhardt et al. 1984, Schoen and Kirchoff 1985, Scarbrough and Krausman 1988, Kufeld and Bowden
1995). A previous study on mule deer in Canada detected fine-scale genetic structure in females, which is consistent with the philopatric tendencies of that sex (Cullingham et al. 2011b).

\section{Methods}

\section{Study Site and Sampling Procedures}

The study was conducted at Fort Carson Military Reservation (FCMR) in the foothills on the eastern slope of the Southern Rocky Mountains, south of Colorado Springs, Colorado. Fort Carson has an area of 55,605 ha and elevations ranging from 1646 to $2103 \mathrm{~m}$. The plant communities include short-grass prairie, riparian wetlands, foothill shrubland, piñon pine-oneseeded juniper (Pinus edulis-Sabina monosperma) woodland, and ponderosa pine (Pinus ponderosa) forest.

The mule deer population includes more than 600 animals scattered across the military post. Hunting is permitted. Deer rarely leave the post, except for a few animals that make short excursions and return. Greater numbers of deer are found at the northern end of the post, whereas fewer deer live on the southern end. In addition, deer tend not to enter a large impact area (8454 ha) on the east central edge of the post.

Using a helicopter and netguns, we captured 34 adult mule deer females (i.e., individuals $>1.5$ years old) on 20-21 March 2010. Our goal was to select females from all areas of the post south of the housing and administrative areas. The only area not selected for capturing deer was the large impact area, which is off-limits to all personnel. Deer were fitted with Globalstar VHF/GPS tracking collars (North Star Science and Technology, King George, VA) designed to transmit a longitude/latitude coordinate via satellite uplink every 3 hours. Coordinates were gathered for approximately 18 months. We collected fecal samples for DNA extraction at the time of capture. DNA extracted from fecal material is sometimes associated with problems arising from low quantity and quality of target DNA and the presence of compounds that can inhibit downstream applications such as the polymerase chain reaction (PCR) (Broquet and Petit 2004). The issue of low DNA quality and quantity is particularly common in noninvasively collected samples from the field, but 
TABLE 1. Primer sequences and size ranges of amplified products.

\begin{tabular}{|c|c|c|c|}
\hline Primer & Sequence & Size range & Source \\
\hline $\mathrm{BBJ} 2$ & $\begin{array}{l}\text { 5'-GCACTTTAGCTCACTTCCTG-3' } \\
\text { 5'-ACACTGCCCCGGTATCTTTG-3' }\end{array}$ & $175-190 \mathrm{bp}$ & Wilson and Strobeck 1999 \\
\hline ETH152 & $\begin{array}{l}\text { 5'-AGGGAGGGTCACCTCTGC-3' } \\
\text { 5'-CTTGTACTCGTAGGGCAGGC-3' }\end{array}$ & 186-204 bp & Steffen et al. 1993 \\
\hline N1 & $\begin{array}{l}\text { 5'-GCAACCAATAGGATAGGTCG-3' } \\
\text { 5'-GCTGGATGGAACTGAAAGTC-3' }\end{array}$ & 253-299 bp & Jones et al. 2000 \\
\hline OvirA & $\begin{array}{l}\text { 5'-CACAAAGAATCAGACGTGGT-3' } \\
5^{\prime} \text {-GTGCATCTCAACATGAGTTAGG-3' }\end{array}$ & 73-102 bp & $\begin{array}{l}\text { Jobin et al. } 2008 \text { after } \\
\text { DeWoody et al. } 1995\end{array}$ \\
\hline RT5 & $\begin{array}{l}\text { 5'-AATTCCATGAACAGAGGAG-3' } \\
\text { 5'-CAGCATAATTCTGACAAGTG-3' }\end{array}$ & $143-161 \mathrm{bp}$ & Wilson et al. 1997 \\
\hline RT7 & $\begin{array}{l}5^{\prime} \text {-CCTGTTCTACTCTTCTTCTC-3' } \\
5^{\prime} \text {-ATCTTTCACGGGCACTGGTT-3' }\end{array}$ & $203-235$ bp & Wilson et al. 1997 \\
\hline RT30 & $\begin{array}{l}\text { 5'-CTGGTGTATGTATGCACACT-3' } \\
\text { 5'-CACTTGGCTTTTGGACTTA-3' }\end{array}$ & 180-206 bp & Wilson et al. 1997 \\
\hline
\end{tabular}

extractions from fresh elephant (Loxodonta africana) dung reliably yielded undegraded DNA that performed as well in downstream analyses as DNA extracted from tissue or blood (Okello et al. 2005). To ensure maximum freshness, we manually extracted fecal samples from deer and then scraped the rectum, which likely increased the number of epithelial cells in our samples. Samples were stored at $-80{ }^{\circ} \mathrm{C}$ until DNA was extracted. Given the potential for contamination with inhibitory compounds, we used the QIAamp DNA Stool Mini Kit (QIAGEN, Hilden, Germany) to extract DNA. The kit is specifically designed to remove such contaminants. Yield and purity of all extractions were analyzed using a NanoDrop 2000 spectrophotometer (Thermo Scientific, Wilmington, DE).

\section{Ethics Statement}

We followed guidelines established by the American Society of Mammalogists for the use of mammals in research (Sikes et al. 2011) and by the University of Colorado Colorado Springs Institutional Animal Care and Use Committee, protocol 10-001. We operated under license number 10TR2050 issued by the Colorado Division of Wildlife and under the auspices of the Fort Carson Directorate of Public Works, Environmental Division Wildlife Office $(38.681120 \mathrm{~N}, 104.838485 \mathrm{~W})$. No endangered species were handled in this study.

The views presented in this work are those of the authors and do not necessarily represent the official policy or position of the Department of Defense (DoD) or any of its subsidiaries. Neither the DoD nor its subsidiaries assumes any legal liability or responsibility for the accuracy, completeness, or usefulness of any information, apparatus, product, or processes disclosed. Reference herein to any specific commercial product, process, or service by trade name, trademark, manufacturer, or otherwise, does not necessarily constitute or imply its endorsement, recommendation, or favoring by the DoD or its subsidiaries.

\section{Spatial Autocorrelation Analysis}

We analyzed genetic variation at 7 previously identified microsatellite loci: BBJ2, RT5, ETH152, N1, RT30, RT7, and OvirA (Steffen et al. 1993, Wilson et al. 1997, Wilson and Strobeck 1999, Jobin et al. 2008; Table 1). Fluorescent-labeled forward primers for these 7 loci were obtained from Life Technologies (Carlsbad, CA). A 4-dye pallet (6FAM, NED, PET, VIC) was selected for capillary electrophoresis analysis using a LIZ ${ }^{\circledR}$-labeled (Applied Biosystems, Inc.) molecular size marker. We amplified DNA using PCR in a 96-well Veriti thermocycler and Amplitaq Gold Fast PCR master mix (Life Technologies, Carlsbad, CA) following the manufacturer's protocol. Genotyping was performed on an ABI3730 DNA analyzer (Life Technologies, Carlsbad, CA) housed in the University of Arizona Genetics Core Facility (Tucson, AZ). Electropherograms for each sample were visualized using Peak Scanner software (Life Technologies, Carlsbad, CA), and alleles were manually scored. The individual who scored genotypes was unaware of position information for the deer used in spatial autocorrelation analysis. 
Spatial autocorrelation analysis and kinship estimates are relatively insensitive to moderate genotyping errors that can arise from the presence of null alleles or allelic dropout (SanCristobal and Chevalet 1997, Sieberts et al. 2002, Wang 2004, Johnson and Haydon 2007, Kelly et al. 2011). Nevertheless, we tested for the presence of errors using Micro-checker 2.2.3 software (Van Oosterhout et al. 2004). We also used Arlequin 3.5 software (Excoffier and Lischer 2010) to test for violations of HardyWeinberg equilibrium, as null alleles and allelic dropout should increase homozygosity.

To investigate fine-scale genetic structure within the study population, we combined genotyping data with spatial information to examine spatial autocorrelation of relatedness (Sokal and Oden 1978). GPS collars recorded position information (latitude/longitude coordinates) every 3 hours for 18 months, resulting in thousands of position coordinates for each deer. Latitude/longitude coordinates were parsed and imported into ArcGIS 10.0 (Esri, Redlands, CA) and then converted to a Universal Transverse Mercator point data layer. The point data layer was used to calculate a mean coordinate for each deer using the Mean Center tool, which uses the average $x$ and $y$ coordinate values to generate an average position. A pairwise euclidian distance between each deer's mean center point was then calculated with the Point Distance tool (Fig. 1). This value was used in the spatial autocorrelation analysis as the distance separating deer in each pairing.

We used the Queller and Goodnight (1989) relatedness estimator in the autocorrelation analysis with SPAGeDi 1.3 software (Hardy and Vekemans 2002). This relatedness estimator does not assume Hardy-Weinberg proportions and calculates relatedness values using population allele frequencies. Positive relatedness values $(r)$ indicate that 2 individuals share more alleles than would be expected given random pairing of alleles, while negative values indicate that the individuals share fewer alleles given random pairing. Our sample size exceeded the number of individuals recommended (Gruell and Papez 1963, Robinette 1966, Hedlund 1975, Harestad and Bunnell 1983, Eberhardt et al. 1984, Schoen and Kirchoff 1985) for producing reliable allele frequency estimates in microsatellite studies (Hale et al. 2012). Autocorrelation was performed using 1000-m bins, chosen both to give a fine spatial scale for the analysis and to keep the number of pairs in each bin reasonably high (although the longest distance classes had relatively few pairs). Average relatedness values were calculated from all available pairs in each distance bin, and standard errors were calculated by the jackknifing procedure available in SPAGeDi that iteratively removes one locus at a time and recalculates relatedness estimates. Tests for statistical significance of spatial autocorrelation were performed using the permutation test available in SPAGeDi software. The permutation test compared observed mean relatedness values in each distance bin with permuted mean relatedness values (with 95\% confidence intervals) expected under the assumption of no spatial autocorrelation. This test yielded the probability ( $P$ value) that the observed relatedness value for a given distance bin was significantly greater than or lower than the value predicted under no spatial structure. Distance bins showing significant autocorrelation were investigated further by calculating the Queller and Goodnight (1989) relatedness coefficient for all pairs within the distance class using COANCESTRY ver 1.0.0.1 (Wang 2011).

\section{RESUlts}

DNA extractions resulted in an average yield of $5.7 \mu \mathrm{g}$ (range 1.5-22.4 $\mu \mathrm{g}$ ), and 260/280 ratios (ratio of absorbance at $260 \mathrm{~nm}$ and $280 \mathrm{~nm}$ ) ranged from 1.6 to 2.1 (with the exception of one sample at 1.5), indicating DNA of sufficient quantity and purity for downstream processing. We successfully obtained 235 out of 238 genotypes (99\%), a further indication that DNA extractions were of high quality. There was no significant $(P<0.05)$ deviation from the Hardy-Weinberg equilibrium at any locus (Table 2). However, analysis by Microchecker suggested that one locus (N1) exhibited evidence of null alleles. Null alleles can bias some population genetic analyses (Van Oosterhout et al. 2004, Kelly et al. 2011), although effects on kinship estimates and spatial autocorrelation specifically appear to be minimal (SanCristobal and Chevalet 1997, Sieberts et al. 2002, Wang 2004, Johnson and Haydon 2007, Kelly et al. 2011). Although null-allele frequency estimates produced by Micro-checker can be used to correct biases in subsequent analyses, we chose the more 


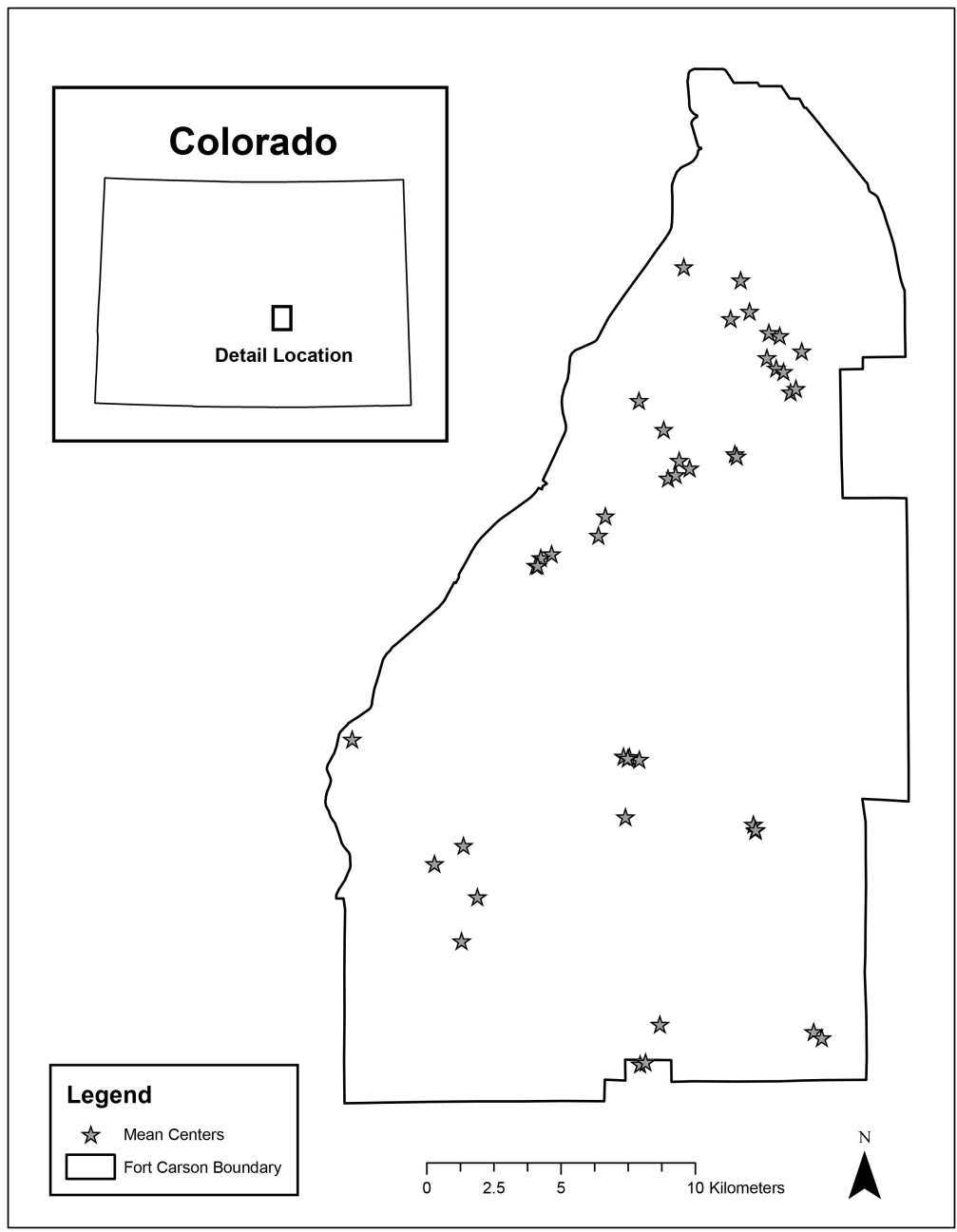

Fig. 1. Locations for mean center points of deer used in the autocorrelation analysis.

TABLE 2. Summary of Hardy-Weinberg equilibrium with the observed heterozygosity $\mathrm{H}_{0}$, expected heterozygosity $\mathrm{H}_{\mathrm{e}}$, number of alleles, and observed fragment size range.

\begin{tabular}{lcccrr}
\hline Locus name & $\mathrm{H}_{\mathrm{o}}$ & $\mathrm{H}_{\mathrm{e}}$ & $P$ value & $\begin{array}{c}\text { Number } \\
\text { of alleles }\end{array}$ & Size range \\
\hline BBJ2 & 0.73529 & 0.79412 & 0.71181 & 7 & $175-190 \mathrm{bp}$ \\
RT5 & 0.75758 & 0.76550 & 0.68865 & 8 & $143-161 \mathrm{bp}$ \\
ETH152 & 0.69697 & 0.80839 & 0.06376 & 9 & $186-204 \mathrm{bp}$ \\
N1 & 0.73529 & 0.89069 & 0.11007 & 12 & $253-299 \mathrm{bp}$ \\
RT30 & 0.76471 & 0.83538 & 0.26112 & 9 & $180-206 \mathrm{bp}$ \\
RT7 & 0.82353 & 0.82090 & 0.27718 & 9 & $203-235 \mathrm{bp}$ \\
Ovir A & 0.78788 & 0.84988 & 0.59873 & 12 & $73-102 \mathrm{bp}$ \\
\hline
\end{tabular}

conservative approach of discarding the locus altogether, as suggested by Pemberton et al. (1995). In the end, the main conclusions from our analysis were the same, whether this locus was included or excluded (data not shown).
We found statistically significant results for autocorrelation of pairwise relatedness within the shortest distance class $(1000 \mathrm{~m} ; n=29$ pairs; $P<0.0001)$ and, unexpectedly, within the 28,000 -m class $(n=5$ pairs; $P=0.0173)$ 


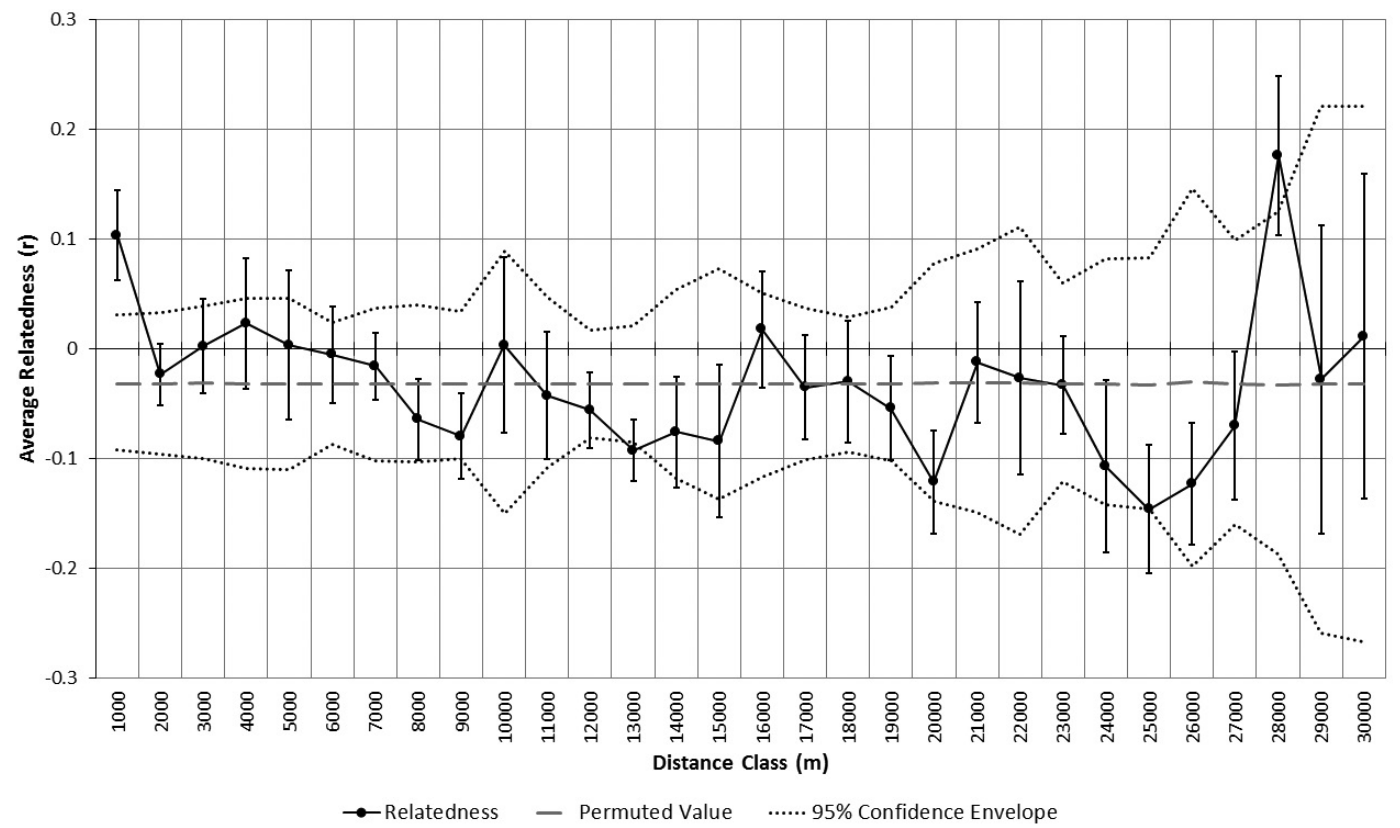

Fig. 2. Autocorrelation analysis of pairwise relatedness performed using the 6 microsatellite loci. The circles show the calculated average Queller and Goodnight (1989) relatedness in each distance class, and the bars represent standard error.

(Fig. 2). To further analyze patterns of relatedness within these distance classes, we plotted pairwise relatedness values against distances separating pairs. Within the 1000-m distance class there appeared to be a mix of related and unrelated pairs (assuming confidence intervals not overlapping zero indicate true relatedness; Fig. 3A). The 28,000-m distance class comprised only 5 pairs, and the high mean relatedness for this group was driven primarily by a single pair that was relatively highly related (Fig. 3B). Thus, although these data suggested that females can disperse over relatively long distances, we did not interpret the significant spatial autocorrelation in this bin as suggesting that this dispersal was necessarily common.

\section{Discussion}

Mule deer exhibit matrilineal social structure in which female offspring tend to be more philopatric than males, and disperse shorter distances than males. Population genetic theory predicts that sex-biased philopatry should lead to positive spatial autocorrelation of relatedness in the philopatric sex, with none in the dispersing sex (Chesser 1991a, Banks and Peakall 2012). Our results concur with 2 previous studies that investigated finescale genetic structure in O. hemionus. Both Sitka black-tailed deer (O. h. sitkensis) and Rocky Mountain mule deer (O. h. hemionus) demonstrated significant spatial autocorrelation, but only in distance classes of $\leq 1000 \mathrm{~m}$ and only in females (Cullingham et al. 2011b, Colson et al. 2013). Our study, together with these previous findings, suggests that finescale genetic structure among related females is characteristic of $O$. hemionus populations, even across diverse habitat types that have been sampled.

Although our overall data fit the expected pattern of fine-scale genetic structure in female deer, we also found evidence of unrelated deer living in close spatial proximity and related deer separated by considerable distance. Spatial overlap of unrelated individuals has also been observed in white-tailed deer $(O$. virginianus), for which it is hypothesized that different social groups may occupy overlapping home ranges (Comer et al. 2005, Miller et al. 2010). Unfortunately, because our telemetry data was not temporally synchronized, we are unable to easily delineate social groups. Thus, we cannot differentiate the possibility that unrelated social groups occupy overlapping 


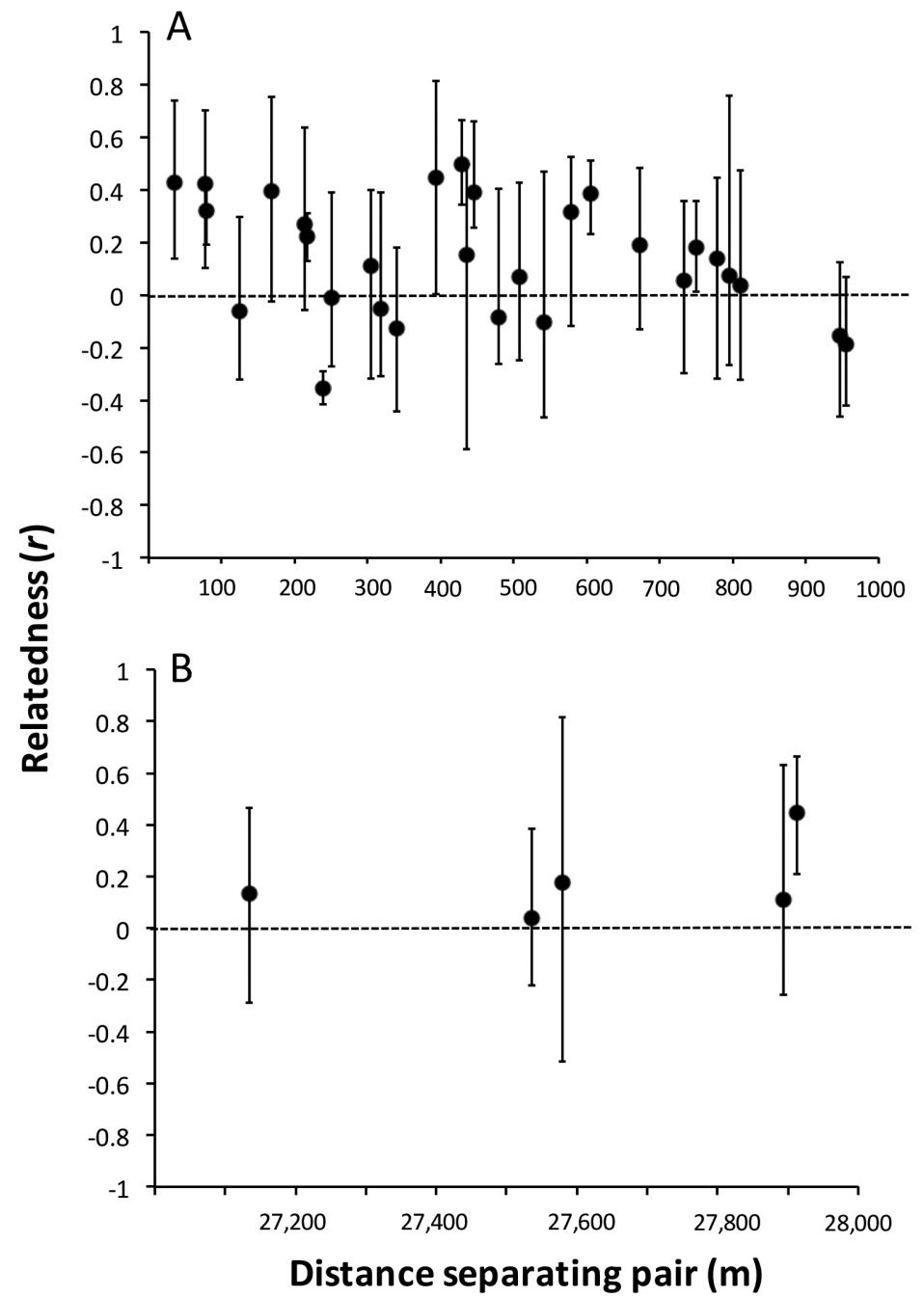

Fig. 3. Pairwise relatedness for pairs of adult female mule deer in the (A) $1000-\mathrm{m}$ and (B) 28,000-m distance class plotted against the euclidean distance separating them. Error bars represent the upper and lower limits of the $95 \%$ confidence interval for the Queller and Goodnight (1989) relatedness that was generated by COANCESTRY (2011).

home ranges but remain distinct, from the alternative that unrelated females occasionally join together in social groups. The fact that the 28,000-m distance class appeared to include at least one pair of related deer also suggests that some female deer disperse considerable distances rather than remain in their natal area. This pattern has also been observed in white-tailed deer, with Miller et al. (2010) reporting the sporadic occurrence of positive autocorrelation at relatively longer spatial distance classes and Comer et al. (2005) observing this pattern even more frequently.
Although it is unclear what factors contribute to differences in female dispersal rates in different populations, previous researchers have hypothesized that variation in the age structure of cervid populations (often resulting from differences in harvest patterns) influences dispersal and ultimately patterns of fine-scale genetic structure (Comer et al. 2005, Miller et al. 2010). Specifically, harvesting young females precludes the establishment of stable multigenerational female groups, and may result in increased dispersal of fawns (Nelson and Mech 1981, Etter et al. 1995). Our study population 
may offer a unique opportunity to further examine the relationship between female dispersal and harvest rates, as the Colorado Department of Parks and Wildlife has recently increased the number of hunting permits allowed on Fort Carson by nearly $50 \%$.

This spatial distribution of mule deer also has implications for control of disease transmission. Although we did not specifically test for chronic wasting disease (CWD), results from deer harvested at FCMR indicate that approximately $20 \%$ of the deer population is infected. In the past, disease transmission modeling has assumed random mixing of individuals in the population (Anderson and May 1992); however, the composition of social groups and intergroup movements likely influence the transmission of pathogens (Loehle 1995, Delahay et al. 2000). Grear et al. (2010) and Cullingham et al. (2011b) demonstrated a strong relationship between infection probability and female relatedness, presumably because closely related females have more contact with each other and thus a greater chance of disease transmission. Kelly et al. (2010) suggested that culling white-tailed deer females within matriarchal groups would help to reduce horizontal transmission of CWD.

Miller and Conner (2005) and Lang and Blanchong (2012) have reported that while both male and female deer are equally susceptible to CWD, males show a higher prevalence of CWD. Miller and Conner (2005) suggested that because males roam widely during the breeding season they more frequently come in contact with infected individuals and contaminated environments. Thus, dispersal of males and genetic relatedness of females remaining in matrilineal groups have both been identified as factors that link individuals infected with CWD in mule deer (Cullingham et al. 2011b) and white-tailed deer (Grear et al. 2010). Future studies on the association between dispersal and infection in our study population will provide further insights into CWD dynamics.

\section{ACKNOWLEDGMENTS}

This research was supported by a grant (W81XWH-09-2-0111) from the U.S. Army Medical Research Acquisition Activity. The views presented in this work are those of the authors and do not represent the official policy or position of the Department of Defense or any of its subsidiaries. No mention of commercial products or services should be interpreted as an endorsement by the Department of Defense or any of its subsidiaries.

\section{Literature Cited}

ANDERSON, R.M., AND R.M. MaY. 1992. Infectious diseases of humans: dynamics and control. Oxford University Press, New York, NY.

Banks, S.C., and R.O.D. PeaKall. 2012. Genetic spatial autocorrelation can readily detect sex-biased dispersal. Molecular Ecology 21:2092-2105.

Bonnot, N., J.-M. Gaillard, A. Coulon, M. Galan, J.-F. Cosson, S. Delorme, F. Klein, and A.J.M. HewiSON. 2010. No difference between the sexes in finescale spatial genetic structure of roe deer. PLOS ONE 5:e14436.

Broquet, T., AND E. Petit. 2004. Quantifying genotyping errors in noninvasive population genetics. Molecular Ecology 13:3601-3608.

Bubenik, A.B. 1985. Reproductive strategies in cervids. Pages 367-373 in P.F. Fennessy and K.R. Drew, editors, Biology of deer production. The Royal Society of New Zealand, Wellington, New Zealand.

Busch, J.D., P.M. Waser, and A.J. DeWoody. 2009. The influence of density and sex on patterns of fine-scale genetic structure. Evolution 63:2302-2314.

Chesser, R.K. 1991a. Gene diversity and female philopatry. Genetics 127:437-447.

Chesser, R.K. 1991b. Influence of gene flow and breeding tactics on gene diversity within populations. Genetics 129:573-583.

Colson, K.E., T.J. Brinkman, D.K. Pearson, and K.J. Hundertmark. 2013. Fine-scale social and spatial genetic structure in Sitka black-tailed deer. Conservation Genetics 14:439-449.

Comer, C.E., J.C. Kilgo, G.J. D’Angelo, T.C. Glenn, AND K.V. MiLLER. 2005. Fine-scale genetic structure and social organization in female white-tailed deer. Journal of Wildlife Management 69:332-344.

CowAN, I.M. 1956. Life and times of the coast black-tailed deer. Pages 523-617 in W.P. Taylor, editor, The deer of North America. Stackpole Co., Harrisburg, PA.

Cullingham, C.I., E.H. Merrill, M.J. Pybus, T.K. Bollinger, G.A. Wilson, and D.W. Coltman. 2011a. Broad and fine-scale genetic analysis of whitetailed deer populations: estimating the relative risk of chronic wasting disease spread. Evolutionary Applications 4:116-131.

Cullingham, C.I., S.M. NaKada, E.H. Merrill, T.K. Bollinger, M.J. Pybus, and D.W. Coltman. 2011 b. Multiscale population genetic analysis of mule deer (Odocoileus hemionus hemionus) in western Canada sheds new light on the spread of chronic wasting disease. Canadian Journal of Zoology 89:134-147.

Cutrera, A.P., E.A. LaCEy, And C. Busch. 2005. Genetic structure in a solitary rodent (Ctenomys talarum): implications for kinship and dispersal. Molecular Ecology 14:2511-2523.

Delahay, R.J., S. Langton, G.C. Smith, R.S. CliftonHadley, and C.L. Cheeseman. 2000. The spatiotemporal distribution of Mycobacterium bovis (bovine tuberculosis) infection in a high-density badger population. Ecology 69:428-441. 
Eberhardt, L.E., E.E. Hanson, and L.L. Cadwell. 1984. Movement and activity patterns of mule deer in the sagebrush-steppe region. Journal of Mammalogy 65:404-409.

Etter, D.R., C.M. Nixon, J.B. Sullivan, And J.A. Thomas. 1995. Emigration and survival of orphaned female deer in Illinois. Canadian Journal of Zoology 73:440-445.

Excoffier, L., AND H.E. Lischer. 2010. Arlequin suite ver 3.5: a new series of programs to perform population genetics analyses under Linux and Windows. Molecular Ecology Resources 10:564-567.

Grear, D.A., M.D. Samuel, K.T. Scribner, B.V. WeckWORTH, AND J.A. LANGENBERG. 2010. Influence of genetic relatedness and spatial proximity on chronic wasting disease infection among female white-tailed deer. Journal of Applied Ecology 47:532-540.

GreenwoOD, P.J. 1980. Mating systems, philopatry and dispersal in birds and mammals. Animal Behaviour 28:1140-1162.

Gruell, G.E., AND N.J. Papez. 1963. Movements of mule deer in northeastern Nevada. Journal of Wildlife Management 27:414-422.

Hale, M.L., T.M. Burg, and T.E. Steeves. 2012. Sampling for microsatellite-based population genetic studies: 25 to 30 individuals per population is enough to accurately estimate allele frequencies. PLOS ONE 7(9):e45170.

Hardy, O.J., and X. Vekemans. 2002. SPAGeDi: a versatile computer program to analyse spatial genetic structure at the individual or population levels. Molecular Ecology Notes 2:618-620.

Harestad, A.S., And F.L. Bunnell. 1983. Dispersal of a yearling male black-tailed deer (Odocoileus hemionus columbianus). Northwest Science 57:45-48.

HedLund, J.D. 1975. Tagging mule deer fawns in southcentral Washington, 1969-1974. Northwest Science 49:153-157.

Hïglund, J., R.V. Alatalo, A. Lundberg, P.T. Rintamîki, AND J. LINDELL. 1999. Microsatellite markers reveal the potential for kin selection on Black Grouse leks. Proceedings of the Royal Society of London, Series B: Biological Sciences 266:813-816.

Jobin, R.M., D. Patterson, and Y. Zhang. 2008. DNA typing in populations of mule deer for forensic use in the province of Alberta. Forensic Science International: Genetics 2:190-197.

Johnson, P.C.D., AND D.T. Haydon. 2007. Maximumlikelihood estimation of allelic dropout and false allele error rates from microsatellite genotypes in the absence of reference data. Genetics 175:827-842.

Kelly, A.C., N.E. Mateus-Pinilla, M. Douglas, M. Douglas, W. Brown, M.O. Ruiz, J. Killefer, P. Shelton, AND J. NOVAKOFSKI. 2010. Utilizing disease surveillance to examine gene flow and dispersal in white-tailed deer. Journal of Applied Ecology 47:1189-1198.

Kelly, A.C., N.E. Mateus-Pinilla, M. Douglas, M. Douglas, P. Shelton, and J. NOVAKOFSKI. 2011. Microsatellites behaving badly: empirical evaluation of genotyping errors and subsequent impacts on population studies. Genetics and Molecular Research 10:2534-2553.

Kufeld, R.C., AND D.C. Bowden. 1995. Mule deer and white-tailed deer inhabiting eastern Colorado plains river bottoms. Technical Bulletin No. 41, Colorado Division of Wildlife, Fort Collins, CO.
LANG, K.R., AND J.A. Blanchong. 2012. Population genetic structure of white-tailed deer: understanding risk of chronic wasting disease spread. Journal of Wildlife Management 76:832-840.

LoeHle, C. 1995. Social barriers to pathogen transmission in wild animal populations. Ecology 76:326-335.

Mathews, N.E., And W.F. PorTer. 1993. Effect of social structure on genetic structure of free-ranging whitetailed deer in the Adirondack Mountains. Journal of Mammalogy 74:33-43.

Mierau, G.W., AND J.L. Schmidt. 1981. The mule deer of Mesa Verde National Park. Mesa Verde Research Series 2. Mesa Verde National Park, Mesa Verde, CO.

Miller, B.F., R.W. DeYoung, T.A. Campbell, B.R. Laseter, W.M. Ford, and K.V. Miller. 2010. Finescale genetic and social structuring in a central Appalachian white-tailed deer herd. Journal of Mammalogy 91:681-689.

Miller, M.W., AND M.M. Conner. 2005. Epidemiology of chronic wasting disease in free-ranging mule deer: spatial, temporal, and demographic influences on observed prevalence patterns. Journal of Wildlife Diseases 41:275-290.

Nelson, M.E., AND L.D. Mech. 1981. Deer social organization and wolf predation in northeastern Minnesota. Wildlife Monographs 77:1-53.

Nussey, D.H., D.W. Coltman, T. Colson, L.E.B. Kruuk, A. Donald, J. Morris, T.H. Clutton-Brock, and J. Pemberton. 2005. Rapidly declining fine-scale spatial genetic structure in female red deer. Molecular Ecology 14:3395-3405.

Okello, J.B.A., G. Wittemyer, H.B. Rasmussen, I. Douglas-Hamilton, S. Nyakaana, P. Arctander, and H.R. Siegismund. 2005. Noninvasive genotyping and Mendelian analysis of microsatellites in African savannah elephants. Journal of Heredity 96:679-687.

Pac, D.F., R.J. Mackie, and H.E. Jorgensen. 1991. Mule deer population organization, behavior and dynamics in a Northern Rocky Mountain environment. Federal Aid in Wildlife Restoration, Job Compliance Report Project W-120-R-7-18. Montana Department of Fish, Wildlife and Parks, Helena, MT.

Pemberton, J.M., J. Slate, D.R. Bancroft, and J.A. BarRETT. 1995. Nonamplifying alleles at microsatellite loci: a caution for parentage and population studies. Molecular Ecology 4:249-252.

Queller, D.C., AND K.F. GoOdNight. 1989. Estimating relatedness using genetic markers. Evolution 43: 258-275.

RobinetTe, W.L. 1966. Mule deer home range and dispersal in Utah. Journal of Wildlife Management 30:335-349.

Russell, C.A., and B.J. Hatchwell. 2001. Experimental evidence for kin-based helping in a cooperatively breeding vertebrate. Proceedings of the Royal Society of London, Series B: Biological Sciences 268:2169-2174.

SanCristobal, M., and C. Chevalet. 1997. Error tolerant parent identification from a finite set of individuals. Genetics Research 70:53-62.

SCarbrough, D.L., and P.R. Krausman. 1988. Sexual segregation by desert mule deer. Southwestern Naturalist 33:157-165.

Schoen, J.W., AND M.D. Kirchoff. 1985. Seasonal distribution and home-range patterns of Sitka black-tailed deer on Admiralty Island, Southeast Alaska. Journal of Wildlife Management 49:96-103. 
Sieberts, S.K., E.M. Wijsman, and E.A. Thompson. 2002 Relationship inference from trios of individuals, in the presence of typing error. American Journal of Human Genetics 70:170-180.

Sikes, R.S., W.S. Gannon, and the Animal Care and Use Committee of the American Society of MamMALOGISTS. 2011. Guidelines of the American Society of Mammalogists for the use of wild animals in research. Journal of Mammalogy 92:235-253.

SoKaL, R.R., AND N.L. Oden. 1978. Spatial autocorrelation in biology: 1. Methodology. Biological Journal of the Linnean Society 10:199-228.

Steffen, P., A. Eggen, G. Stranziger, R. Fries, A.B. DiETZ, AND J.E. WOMACK. 1993. Isolation and mapping of polymorphic microsatellites in cattle. Animal Genetics 24:121-124.

StorZ, J.F. 1999. Genetic consequences of mammalian social structure. Journal of Mammalogy 80:553-569.

Sugg, D.W., R.K. Chesser, F.S. Dobson, AND J.L. HoogLAND. 1996. Population genetics meets behavioral ecology. Trends in Ecology and Evolution 11:338-342.
Van Oosterhout, C., W.F. Hutchinson, D.P. WiLls, and P. SHIPLEY. 2004. Micro checker: software for identifying and correcting genotyping errors in microsatellite data. Molecular Ecology Notes 4:535-538.

WANG, J. 2004. Sibship reconstruction from genetic data with typing errors. Genetics 166:1963-1979.

WANG, J. 2011. COANCESTRY: a program for simulating, estimating and analyzing relatedness and inbreeding coefficients. Molecular Ecology Resources 11:141-145.

Wilson, G.A., and C. Strobeck. 1999. The isolation and characterization of microsatellite loci in bison, and their usefulness in other artiodactyls. Animal Genetics 30:226-227.

Wilson, G.A., C. Strobeck, L. Wu, and J.W. Coffin. 1997. Characterization of microsatellite loci in caribou Rangifer tarandus, and their use in other artiodactyls. Molecular Ecology 6:697-699.

Received 5 January 2016 Accepted 4 August 2016 